\title{
Coagulation/Flocculation of Tannery Wastewater Using Immobilized Chemical Coagulants
}

\author{
Q. Imran $\star^{1}$, M. A. Hanif ${ }^{2}$, M. S. Riaz ${ }^{3}$, S. Noureen ${ }^{4}$, T. M. Ansari ${ }^{5}$, H. N. Bhatti ${ }^{6}$ \\ 1,3,4,5 Department of Environmental Sciences, \\ GC University Faisalabad-38000-Pakistan. \\ ${ }^{2,6}$ Department of Chemistry and Biochemistry, \\ University of Agriculture, Faiasalabad-38040- Pakistan. \\ *muhammadasifhanif@ymail.com
}

\begin{abstract}
Chemical coagulants were immobilized into bead form using sodium alginate to treat tannery wastewater samples. The used chemical coagulants were ammonium aluminium sulphate $\left(\mathrm{NH}_{4} \mathrm{Al}\left(\mathrm{SO}_{4}\right)_{2}\right)$, aluminium sulphate $\left(\mathrm{Al}_{2}\left(\mathrm{SO}_{4}\right)_{2}\right.$, calcium carbonate $\left(\mathrm{CaCO}_{3}\right)$, sodium citrate $\left(\mathrm{Na}_{3} \mathrm{C}_{6} \mathrm{H}_{5} \mathrm{O}_{7}\right)$. The effect of the chemical coagulant dose and tannery wastewater $\mathrm{pH}$ was studied on wastewater electrical conductance (EC), total dissolved solids (TDS), sulphates, chlorides, phenolphthalein alkalinity, total alkalinity and chemical oxygen demand (COD). The quantity of various pollutants present in waste water was reduced after treatment. The optimized dose and $\mathrm{pH}$ for maximum decrease in EC and TDS were $5 \mathrm{~g} / \mathrm{L}$ and 7 , respectively. The maximum reduction in the amount of sulphates and chlorides present in tannery wastewater was observed at dosage of $0.5 \mathrm{~g} / \mathrm{L}$ and $\mathrm{pH} 7$. A dosage of $5 \mathrm{~g} / \mathrm{L}$ and $\mathrm{pH} 7$ was also found most favorable for maximum reduction in values of COD, phenolphtalein and total alkalinity. The chromium concentrations in tannery wastewater before and after treatment were determined by atomic absorption spectrophotometer. A reduction in chromium concentration was observed after treatment. The promising results of the present study demonstrate that immobilization of chemical coagulants can make them more effective for wastewater treatment.
\end{abstract}

Keywords Coagulation, flocculation, immobilization, tannery wastewater, chemical coagulants

\section{Introduction}

The enormous use of water in industries has caused a serious problem of drainage of industrial waste water. Effluents from industries are deteriorating the surface and underground water quality through seepage, due to chemical constituents of undesirable concentration and thus creating water pollution. Heavy metals are groups of pollutants which are nonbiodegradable and tend to accumulate in living organisms [1]. Heavy metals are toxic because they cannot be degraded biologically into harmless products, hence they cause serious health hazards [2]. All heavy metals at high concentrations have strong toxic effects and are an environmental threat [3]. The pollutants of tannery wastes are of inorganic, organic and toxic nature and require elaborate treatment before disposal to prevent physical, chemical and biological pollution of the receiving body of water. The tannery wastewater with high concentration of dissolved solids, suspended solids, chloride, color, ammonia etc. is being discharged every day in the receiving water.

Coagulation and flocculation processes are intended to form particles large enough to be separated and removed by subsequent sedimentation, or alternative clarification processes. The coagulation stage occurs when a coagulant, such as alum, is added to the water to neutralize the charges on the colloidal particles in the raw water, thus bringing the particles closer together to allow a floc to begin to form. The flocculation process, following coagulation, allows smaller particles formed during the rapid coagulation stage to agglomerate into larger particles to form settleable and/or filterable floc particles. Numerous substances have been used as coagulant and flocculation aids, including alum $\left[\begin{array}{llll}\mathrm{Al}_{2} & \left(\mathrm{SO}_{4}\right)_{3} & 18 \mathrm{H}_{2} \mathrm{O}\end{array}\right]$, ferric chloride $\left[\mathrm{FeCl}_{3}\right.$ $\left.16 \mathrm{H}_{2} \mathrm{O}\right]$, ferric sulfate $\left[\mathrm{Fe}_{2}\left(\mathrm{SO}_{4}\right)_{3}\right]$, ferrous

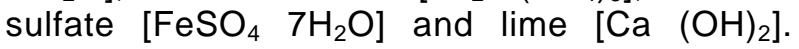
When alum is added to wastewater, the following reaction takes place: 


$$
\mathrm{Al}_{2}(\mathrm{SO} 4)_{3} \cdot 18 \mathrm{H}_{2} \mathrm{O}+3 \mathrm{Ca}\left(\mathrm{HCO}_{3}\right)_{2} \longrightarrow 3 \mathrm{CaSO}_{4}+2 \mathrm{Al}(\mathrm{OH})_{3}+6 \mathrm{CO}_{2}+18 \mathrm{H}_{2} \mathrm{O}
$$

The insoluble aluminum hydroxide, $\mathrm{Al}(\mathrm{OH})_{3}$, is a gelatinous floc that settles slowly through the wastewater, sweeping out the suspended material. Chemical coagulation in the water treatment is the process of bringing suspended matter in untreated water together for the purpose of settling and for the preparation of the water for filtration [4]. Coagulation involves three specific steps which are Coagulation, Flocculation, and Sedimentation. Coagulation can be a simple and inexpensive way to improve the quality of wastewater. Coagulation can improve the quality of water. This improves taste and odor, makes the water safer for chlorination, and makes the water easier to treat for domestic purposes.

The present study was undertaken with the following objectives:

- To evaluate the removal of pollutants from the tannery wastewater by using immobilized chemical coagulants,

- To investigate the different parameters such as $\mathrm{pH}, \mathrm{EC}, \mathrm{TDS}$, chlorides, sulfates and alkalinity,

- To determine chromium concentration in tannery wastewater before \& after treatment using immobilized chemical coagulants.

\section{Materials and methods}

\subsection{Chemical Coagulants}

The chemical coagulants used in the present study were Ammonium aluminium sulphate, aluminium sulphate, calcium carbonate and sodium citrate. These compounds were purchased from $\mathrm{BDH}$ chemicals.

\subsection{Immobilization procedure (beads formation)}

Coagulant $5 \mathrm{~g}$ and $2.5 \mathrm{~g}$ sodium alginate were added to $250 \mathrm{~mL}$ deionized distilled water (DDW). This solution was mixed thoroughly and afterwards heated $\left(\right.$ at $40^{\circ} \mathrm{C}$ ) on the hot plate until solution became homogeneous. Afterwards, the solution was introduced drop-wise using a burette into $0.1 \mathrm{M}$ $\mathrm{CaCl}_{2} 2 \mathrm{H}_{2} \mathrm{O}$ solution. The size of formed beads was $0.350 \mathrm{~mm}$. The immobilized chemical coagulants were preserved in $50 \mathrm{mM} \mathrm{CaCl}{ }_{2}$ solution until use. The dry weights of coagulant beads were determined after drying them at $60^{\circ} \mathrm{C}$ for $48 \mathrm{~h}$. The doses of chemical coagulants were applied on their dry weight basis. Effect of chemical coagulant dose on the tannery wastewater treatment was studied by varying doses from $0.5 \mathrm{~g} / \mathrm{L}$ to $5 \mathrm{~g} / \mathrm{L}$ at constant $\mathrm{pH}$ of 8.2. The effect of $\mathrm{pH}$ on coagulation/flocculation of tannery wastewater was studied by varying $\mathrm{pH}$ from (3 to 7 ) at a fixed chemical coagulant dose of $1 \mathrm{~g} / \mathrm{L}$. In each experiment $24 \mathrm{~h}$ contact time was selected. After completion of the experiment, beads and flocs were separated from each other using Whatman filter paper no.40.

Phenolphthalein alkalinity, total alkalinity, chloride and sulphate were determined according to standard methods described in Water Quality Monitoring Guide published by UNEPMHO [5]. $\mathrm{pH}$ and COD of tannery wastewater were determined using A.V. pH meter (HM3OP) and Merck COD reactor. EC and TDS were determined using EC and TDS meter, respectively. Chromium concentrations were measured by atomic absorption spectrophotometry (AAnalysist 300, PerkinElmer) using an air acetylene flame and single element hollow cathode lamps. The instrument was calibrated using appropriate standard solutions.

\section{Results and discussion}

\subsection{Electrical conductance (EC) and total dissolved solids (TDS)}

The effect of wastewater $\mathrm{pH}$ and coagulant dose on EC and TDS are shown in Figures1 and 2. The maximum removal of EC and TDS was observed at $0.5 \mathrm{~g} / \mathrm{L}$ (Figure 1a) and at pH 3 (Figure 1b). In another study, Hanif et al (2008) [6] observed maximum reduction of $77.62 \%$ and $88.68 \%$ in EC of dying and finishing units of textile industry wastewater at a coagulant dose of $1.5 \mathrm{~g} / \mathrm{L}$. The same authors found that a dose $0.5 \mathrm{~g} / \mathrm{L}$ was the best dose for maximum reduction in TDS value. The reduction in TDS value of textile industry dying and finishing units was $86.02 \%$ and $88.39 \%$, respectively. In the present study, chemical coagulants were immobilized into calcium alginate beads for their more effective use. The initial $\mathrm{pH}$ of tannery wastewater used in the present study was 8.2. The $\mathrm{pH}$ of tannery wastewater was changed after treatment. This change in $\mathrm{pH}$ may have been due to the removal of some suspended and dissolved compounds from tannery wastewater. 

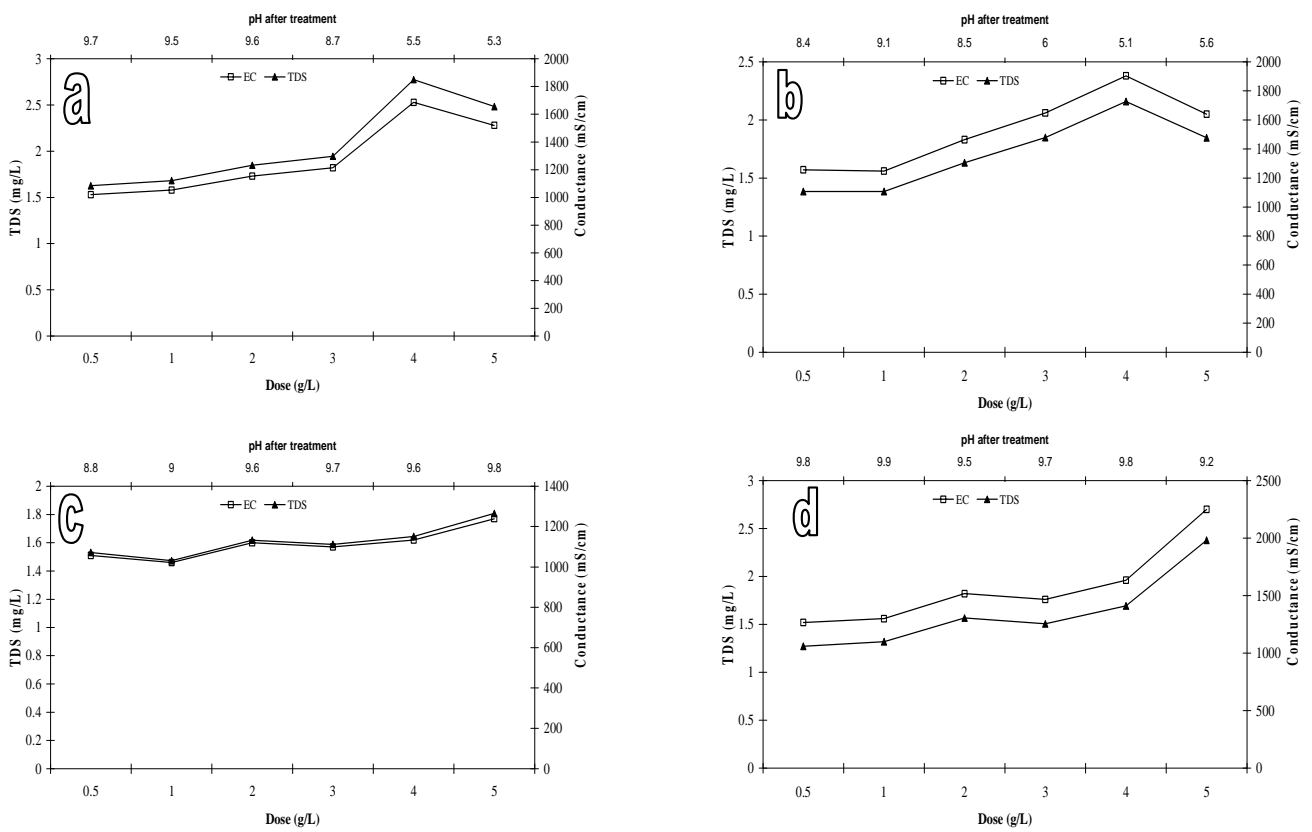

Figure 1. Effect of coagulant dose on EC and TDS of tannery wastewater: (a) Ammonium aluminium sulphate. (b) Aluminium sulphate. (c) Calcium carbonate. (d) Sodium citrate.
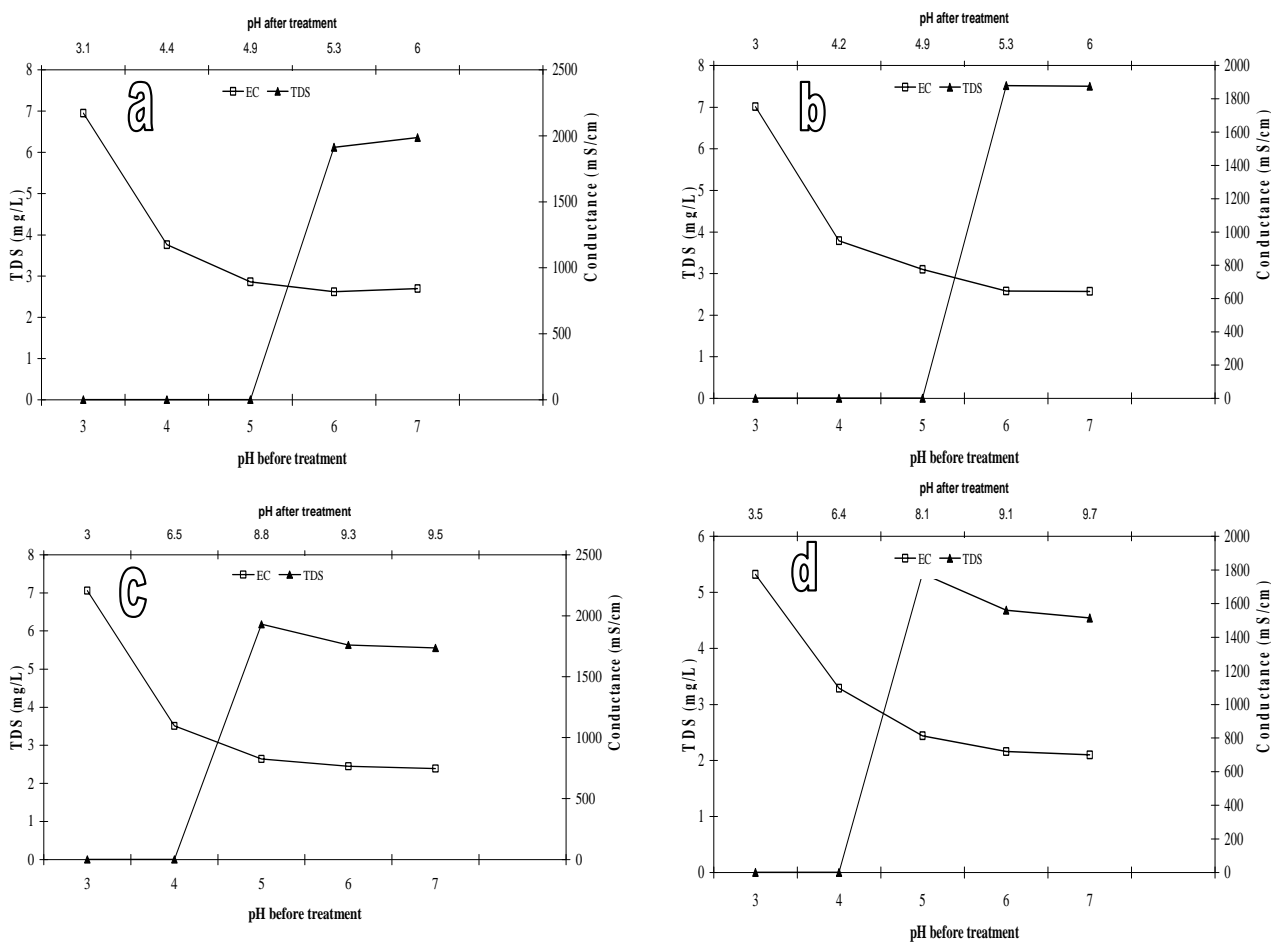

Figure 2. (a) Effect of $\mathrm{pH}$ of ammonium aluminium sulphate on removal of EC and TDS.

(b) Effect of $\mathrm{pH}$ of aluminium sulphate on removal of EC and TDS. (c) Effect of $\mathrm{pH}$ of sodium citrate on removal of EC and TDS. (d) Effect of $\mathrm{pH}$ of calcium carbonate on removal of EC and TDS. 


\section{Coagulation/Flocculation of Tannery Wastewater Using Immobilized Chemical Coagulants, Q. Imran et al. / 79-86}

\subsection{Chlorides and Sulphates}

The effect of wastewater $\mathrm{pH}$ and coagulant dose on chlorides and sulphates is shown in Figures 34. The maximum chloride and sulphate removal was observed at a dose of $5 \mathrm{~g} / \mathrm{L}$ using immobilized chemical coagulants. In a previous study, Suschka and Przywara [7] also detected high amounts of sulphates in wastewater. They concluded that sulphate should be removed before discharge of industrial wastewater into municipal wastewater. In another study, Khanal and Huang [8] effectively reduced the sulphate concentration from 1000,3000 and $5000 \mathrm{mg} / \mathrm{L}$ in effluent to 84, 984 and $1340 \mathrm{mg} \mathrm{SO} / \mathrm{L}$, respectively. The maximum removal of chlorides occurred at $\mathrm{pH} 7$ whereas that of sulphate was at $\mathrm{pH} 3$.
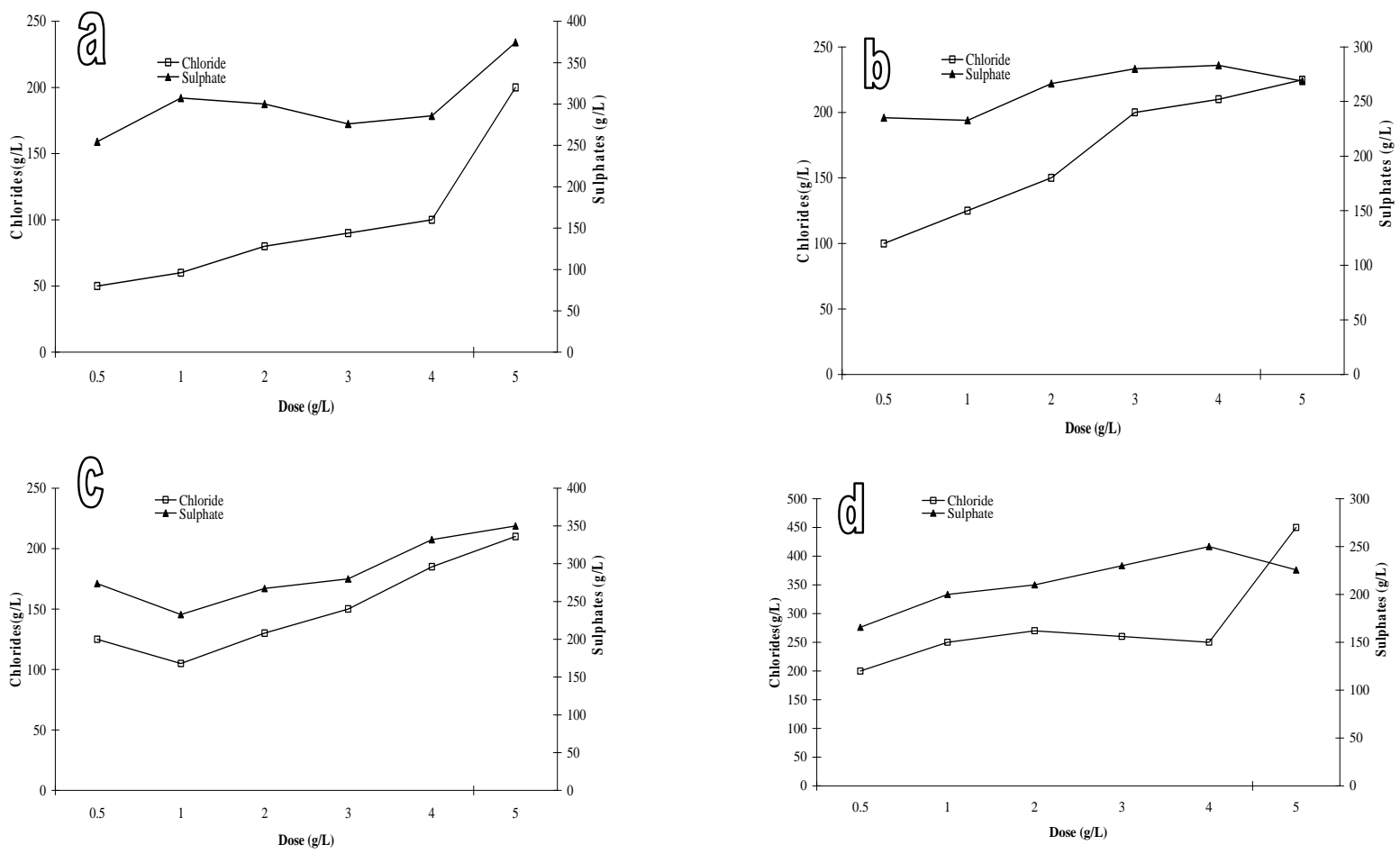

Figure 3. (a) Effect of dose of ammonium aluminum sulphate on reduction of sulphates and chlorides.

(b) Effect of dose of aluminium sulphate on reduction of sulphates and chlorides.

(c) Effect of dose of calcium carbonate on reduction of sulphates and chlorides.

(d) Effect of dos of sodium citrate on reduction of sulphates and chlorides. 

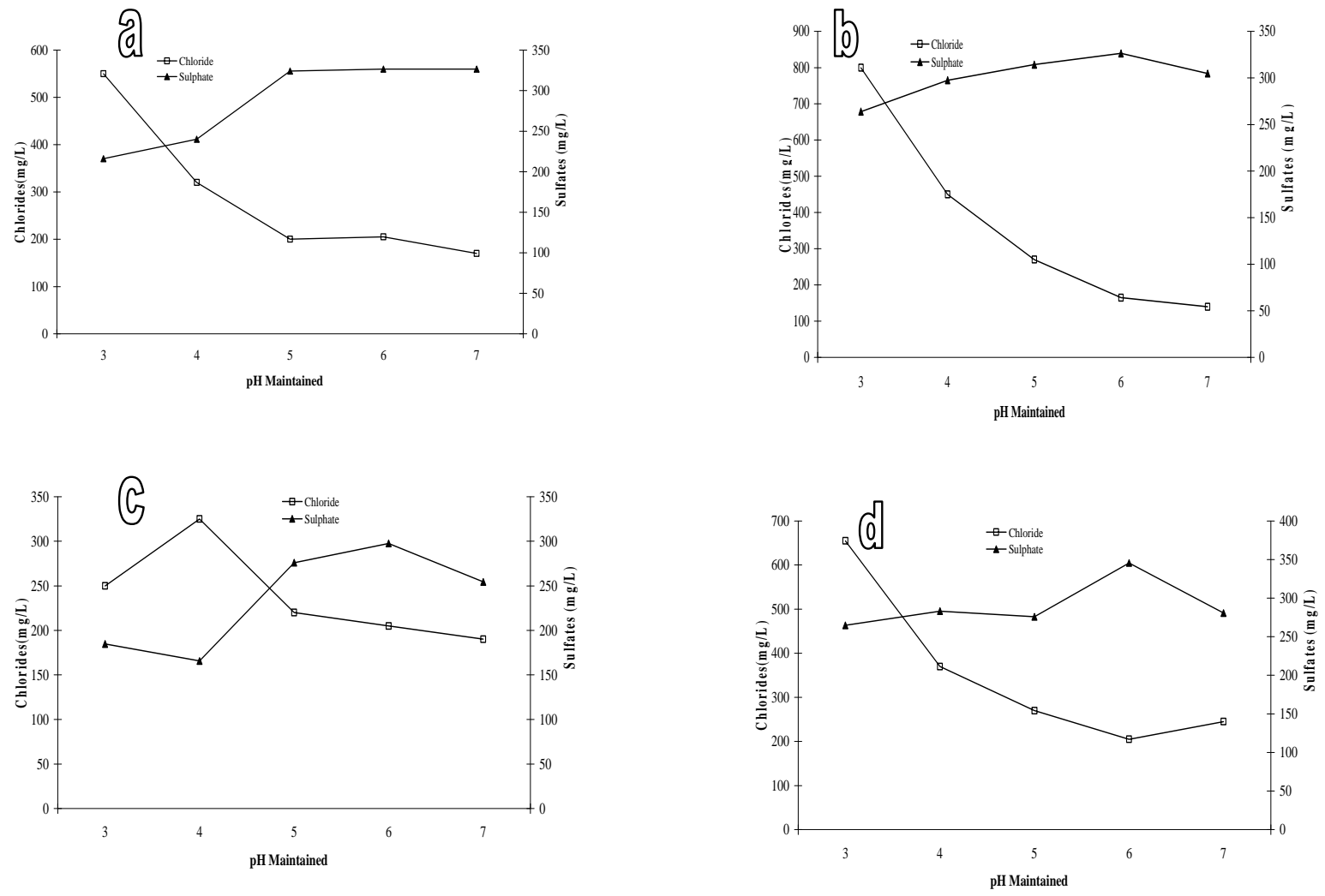

Figure 4. (a) Effect of $\mathrm{pH}$ of ammonium aluminium on reduction of sulphates and chlorides.

(b) Effect of $\mathrm{pH}$ of aluminium sulphate on reduction of sulphates and chlorides.

(c) Effect of $\mathrm{pH}$ of calcium carbonate on reduction of sulphates and chlorides.

(d) Effect of $\mathrm{pH}$ of sodium citrate on reduction of sulphates and chlorides.

\subsection{Chlorides and Sulphates}

At a dose of $5 \mathrm{~g} / \mathrm{L}$, there was maximum reduction in COD (Figure 5). The best $\mathrm{pH}$ for maximum reduction in COD was 7 (Figure 6). Meyssam and Kasaeian [9] carried out maximum COD reduction of $95 \%$ from olive oil emulsion. Aboulhassan et al [10] found $\mathrm{FeCl}_{3}$ an efficient coagulant at $\mathrm{pH}$ range 8-9 and at optimal dose of $650 \mathrm{mg} / \mathrm{L}$. Iron chloride allowed the removal of $82 \%$ of chemical oxygen demand (COD), at optimum condition in their study. They concluded their study by saying that "sequential addition of coagulant and polymeric additives enhance clearly pollutant removal and produces less decanted sludge compared to the results obtained when the coagulant is used alone." Haydar and Aziz [11] found that the combination of alum with cationic polymer C-492 resulted in effluent turbidity removal of $97 \%$, total suspended solids (TSS) removal of $93.5 \%$, total chemical oxygen demand (TCOD) removal of $36.2 \%$ and chromium removal of $98.4 \%$. For this combination the optimum dose of alum was 100 $\mathrm{mg} / \mathrm{L}$ as $\mathrm{Al}_{2}\left(\mathrm{SO}_{4}\right)_{3}$ with $5 \mathrm{mg} / \mathrm{L}$ of $\mathrm{C}-496$. The combination of alum with suitable anionic polymer A-100 resulted in effluent turbidity removal of $99.7 \%$, TSS removal of $96.3 \%$, TCOD removal of $48.3 \%$ and chromium removal of $99.7 \%$. The results of the above combinations were compared with those when alum was used alone for the treatment. The comparison revealed that the use of coagulant aid reduced the sludge volume by 60 $70 \%$ and the cost of chemicals by $50 \%$ for comparable removal efficiency. 

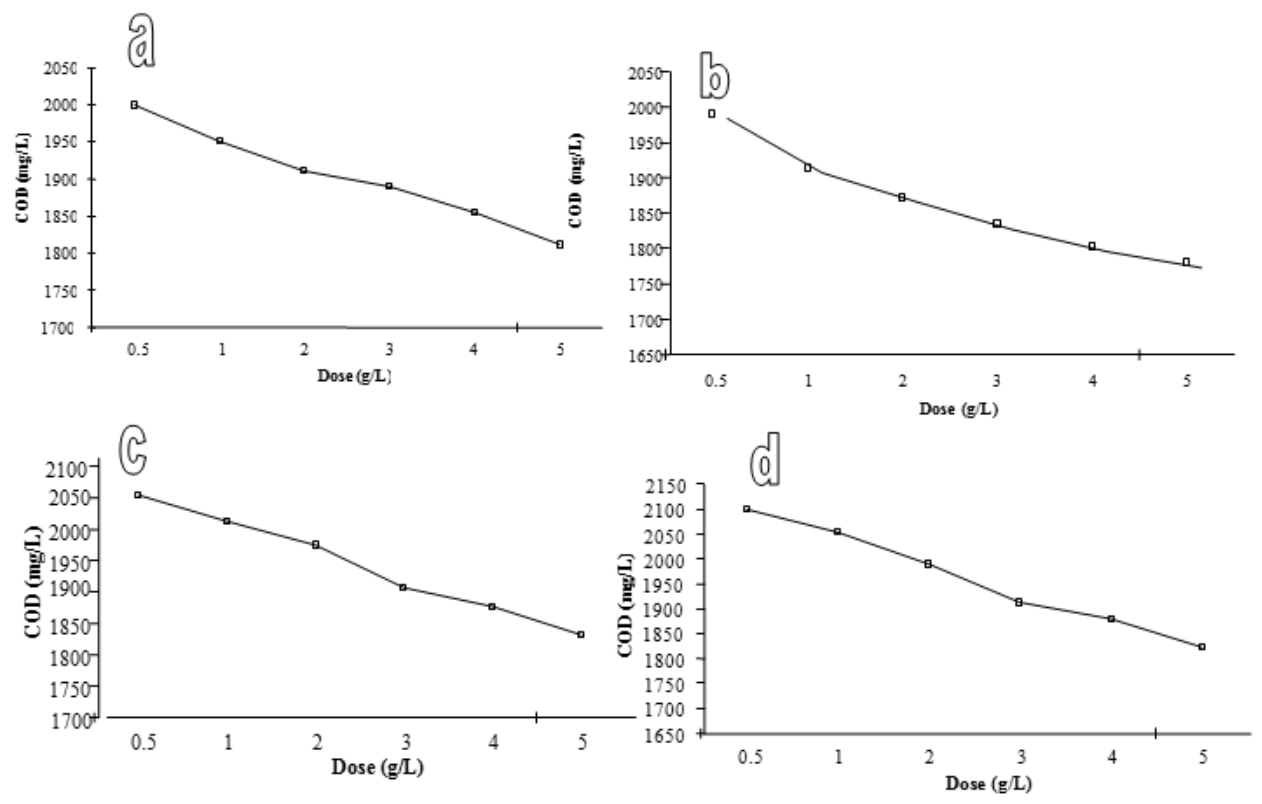

Figure 5. Effect of coagulant dose on COD of tannery wastewater

(a) Ammonium aluminium sulphate. (b) Aluminium sulphate.

(c) Calcium carbonate. (d) Sodium citrate.
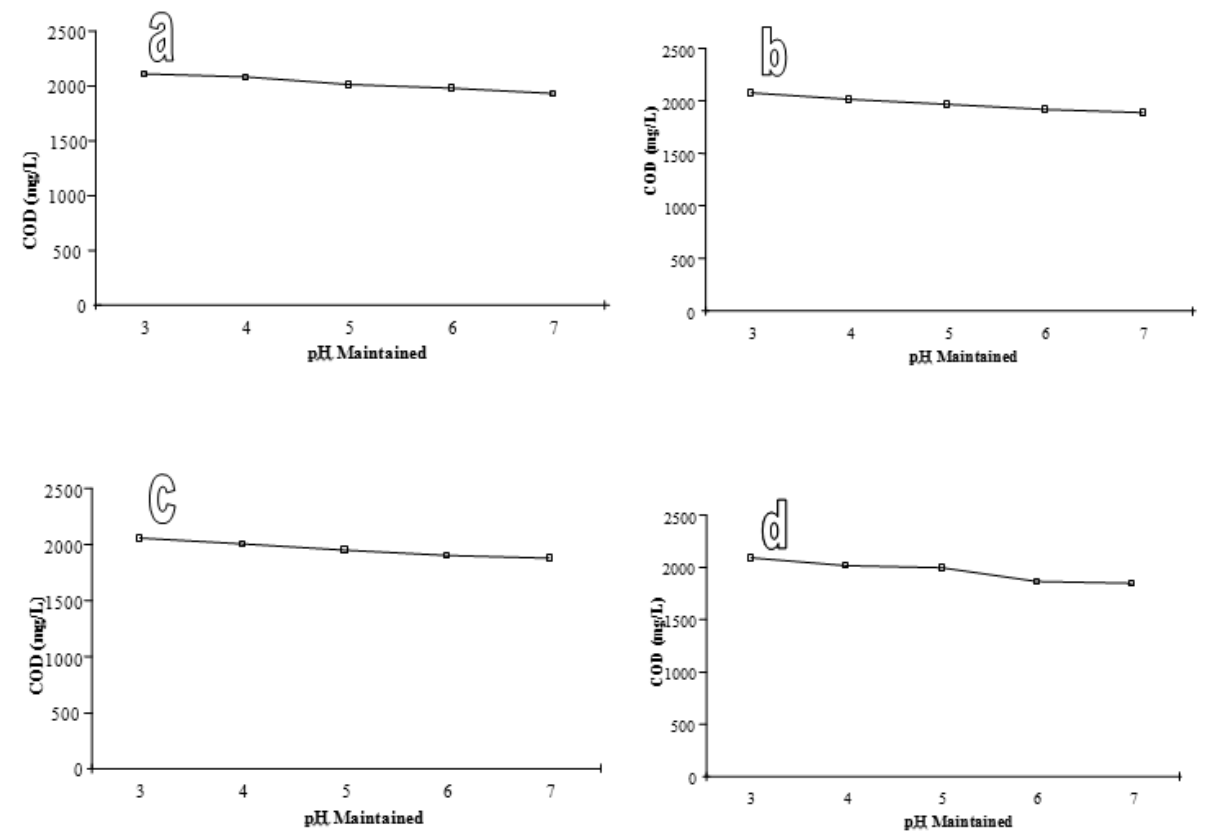

Figure 6. Effect of pH on COD of tannery wastewater (a)Ammonium aluminium sulphate. (b)Aluminium sulphate.

(c) Calcium carbonate. (d) Sodium citrate. 


\subsection{Phenolphthalein and Total Alkalinity}

In the present study increasing the dosage of chemical coagulants from $0.5 \mathrm{~g} / \mathrm{L}$ to $5 \mathrm{~g} / \mathrm{L}$ resulted in increased reduction in phenolphthalein and total alkalinity values. The immobilized coagulants were found to be highly effective in producing low alkalinity wastewater. Hanif et al. [6] found that overall reduction in alkalinity was only $30 \%$ for textile industry wastewater after treatment using a natural coagulant. In the present study, increase in $\mathrm{pH}$ from 3 to 7 reduced phenolphthalein and total alkalinity. Bann et al. [12] found that alkalinity plays an important role in the removal of some other inorganic contaminants present in wastewater. Hanif et al [6] found that optimum $\mathrm{pH}$ for better coagulation was 6 for textile industry wastewater. The figures and oblige tables of alkalinity data are not presented here as in most of cases alkalinity was in required range after treatment.

\subsection{Chromium removal}

The chromium concentration in collected effluent was $3.19 \mathrm{mg} / \mathrm{L}$. After treatment, in most of cases this value reduced to $>0.5 \mathrm{~g} / \mathrm{L}$ (Table 1 ). The results obtained suggest effectiveness of immobilized chemical coagulants in chromium removal from wastewater too.

\section{Conclusions}

Immobilized chemical coagulant dose and wastewater $\mathrm{pH}$ affected the efficiency of the coagulation/flocculation process. After immobilization, chemical coagulants were found more effective for reduction in EC, TDS, phenolphthalein, total phenolphthalein, COD and chromium amount in comparison to their native forms. Immobilized ammonium aluminium sulphate were found more effective for the chromium removal from tannery industry wastewater. The results of the present study clearly demonstrate that the immobilization of chemical coagulants (already in use) can enhance their effectiveness in the pollution removal processes.

\begin{tabular}{|c|c|c|}
\hline $\begin{array}{l}\text { Immobilized } \\
\text { Coagulant }\end{array}$ & $\begin{array}{l}\text { Dose } \\
\text { (g/L) }\end{array}$ & $\begin{array}{l}\text { Chromium } \\
\text { after treatment } \\
\text { (mg/L) }\end{array}$ \\
\hline \multirow{6}{*}{$\begin{array}{l}\text { Sodium } \\
\text { citrate }\end{array}$} & 0.5 & 0.39 \\
\hline & 1 & 0.31 \\
\hline & 2 & 0.21 \\
\hline & 3 & 0.14 \\
\hline & 4 & 0.05 \\
\hline & 5 & 0.01 \\
\hline \multirow{6}{*}{$\begin{array}{l}\text { Ammonium } \\
\text { aluminium } \\
\text { sulphate }\end{array}$} & 0.5 & 0.37 \\
\hline & 1 & 0.28 \\
\hline & 2 & 0.19 \\
\hline & 3 & 0.10 \\
\hline & 4 & 0.04 \\
\hline & 5 & 0.01 \\
\hline \multirow{6}{*}{$\begin{array}{l}\text { Aluminium } \\
\text { sulphate }\end{array}$} & 0.5 & 0.69 \\
\hline & 1 & 0.56 \\
\hline & 2 & 0.45 \\
\hline & 3 & 0.34 \\
\hline & 4 & 0.26 \\
\hline & 5 & 0.14 \\
\hline \multirow{6}{*}{$\begin{array}{l}\text { Calcium } \\
\text { carbonate }\end{array}$} & 0.5 & 0.78 \\
\hline & 1 & 0.67 \\
\hline & 2 & 0.53 \\
\hline & 3 & 0.41 \\
\hline & 4 & 0.32 \\
\hline & 5 & 0.19 \\
\hline
\end{tabular}

Table 1. Chromium concentration in tannery wastewater after treatment using immobilized chemical coagulant (initial chromium concentration $=3.19 \mathrm{mg} / \mathrm{L}$ ) 


\section{References}

[1] M. Kobya, E. Demirbas, E. Senturk, M. Ince, Adsorption of heavy metal ions from aqueous solutions by activated carbon prepared from apricot stone, Bioresource Technology. 96(2005) 1518-1521.

[2] D. Park, S.Y Yun M.J. Park, Use of dead fungal biomass for the detoxification of hexavalent chromium screening and kinetics. Process Biochemistry. 40(2004) 2559-2565.

[3] Ebeling, Evaluation of chemical coagulation_/flocculation aids for the removal of suspended solids and phosphorus from intensive recirculating aquaculture effluent discharge, Aquacultural Engineering. 29 (2003) 23-42.

[4] T.V. Nedelkoska, M.P. Doran, CHARACTERISTIC of heavy metal uptake by plant specie with potential for phytoremediation and phytomining, Minerals Engineering. 13(2000) 549-561.

[5] R. Balance, Physical and Chemical Analyses. Water Quality Monitoring- A Practical Guide to the Design and Implementation of Freshwater Quality Studies and Monitoring Programmes, UNEP/WHO, Ch 7, 1 (1996).

[6] A.M.Hanif, R.Nadeem, N.M. Zafar, N.H.Bhatti, R.Nawaz., physico-chemical treatment of textile wastewater using natural coagulant Cassia fistula (Golden Shower) pod biomass, j.chem.soc.pak. 30 (2008).

[7] J.Suschka, L. Przywara, chemical and biological sulfates removal, 43-309

[8] K.S.Khanal, J.Huang, ORP-based oxygenation for sulfide control in anaerobic treatment of high-sulfate wastewater, Wat. Res.37 (2003) 2053-2062.

[9] Meyssami, B.A. Kasaeian, Use of coagulants in treatment of olive oil wastewater model solutions by induced air flotation, Bioresource Technology. 96(2005) 303-307.

[10] A.M.Aboulhassan, S. Souabi ,A. Yaacoubi ,M. Baudu,Improvement of paint effluents coagulation using natural and synthetic coagulant aid,. Hazardous Materials. 138(12006) 40-45.

[11] S.Haydar, A.J. Aziz, Coagulation/flocculation studies of tannery wastewater using combination of alum with cationic and anionic polymers, Hazardous Materials.168 (2009) 1510.

[12] J.R.Bann; U.K. Do, T.I. Yeom, Phosphorus removal in low alkalinity secondary effluent using alum Environ. Sci. Tech. 5 (2008) 93-98. 